\title{
Eat or Be Eaten: A Feminist Phenomenology of Women as Food
}

\author{
EMILy R. Douglas
}

This paper focuses on women in the food chain, not in terms of agricultural labour, but as food ourselves. Feminist philosophers such as Simone de Beauvoir, Susan Bordo, Iris Marion Young, and Sandra Bartky — among numerous others — have argued that our lived embodiment is philosophically important since it is subject to discipline, power, and contingencies. Our bodies are experienced through and conditioned by our social status, gender, race, and ability. Much of this work draws upon phenomenology, arguing that our bodies are not separated from our subjectivities but are one and the same. However, little feminist philosophical analysis has been done on the role of our bodies as food. I argue that paying philosophical attention only to how the body is shaped, viewed, and touched neglects a dimension of our materiality: what Val Plumwood calls "foodiness" and what I will primarily refer to as edibility. In this paper, I argue that seeing ourselves as edible, beginning with women as edible, can result in both a new ontoecological ethics and to a new understanding of the life/death/life cycle. I will pursue this argument first by contesting the traditional image of the food chain and of humans eating, through the works of Eva-Maria Simms and Val Plumwood. Both of these authors detail instances of philosophical importance that demonstrate how very edible the human subject is. Following this examination, I will formulate an extension of Maurice Merleau-Ponty's ontology, where just as visibility is essentially reversible, edibility is also a condition of our existence. 
First, I will circumscribe the meaning of eating or consumption. Human beings 'consume' the world in a variety of ways, showing that neither 'the world' nor 'the human being' are impenetrable, autonomous, unrelated subjects that stand in external relations. I use the terms consumption or eating widely: we consume non-human animals, plants, minerals and vitamins, airborne toxins, oxygen, bacteria - all of these can provide us with an élan vital, energy, or fuel. Our consumption is ubiquitous - and yet so is the consumption of human beings. From microscopic parasites to other humans or large animals, we provide energy and food for others.

Investigating edibility is important because it can be one factor in defeating the image of the (hu)man as reigning supreme, impenetrable, tied to a mind rather than a body, etc. More than this, I believe we should look at female or feminine edibility. Because women are already represented as edible, analyzing their empirical edibility allows us to see humanity's edibility and environmental interconnection more clearly. In addition, I believe that this analysis of woman's edibility has the potential to unsettle the objectivization of women (her being edible does not make her a mere object), without endorsing the autonomous, rationalist subject.

\section{The Food Chain and Edible Women}

Recall the traditional image of the food chain: man is at the top of a pyramid, below which lie the animals we eat, other animals, plants, insects, and microorganisms. This picture comes to us in part from Aristotle, who presented the food chain as a scale of perfection. Humans, he claimed, are the most perfect beings and so can use all other organisms without any ethical quandry: 
After the birth of animals, plants exist for their sake, and that the other animals exist for the sake of man, the tame for use and food, the wild, if not all at least the greater part of them, for food, and for the provision of clothing and various instruments. Now if nature makes nothing incomplete, and nothing in vain, the inference must be that she has made all animals for the sake of man. (Politics 1, Part VIII)

Aristotle and Aristotelians would regard a bear, or a crocodile, eating a human as perverse and unnatural because it violates this scale of perfection. Indeed, many individuals today would agree. Yet we know that such eating does happen, and environmental and animal activists might argue that it is a natural act. I wish to draw upon Simms and Plumwood's disruptions of our traditional, Aristotelian image of the food chain to show that humanity's place is not at the unreachable heights, but entwined and entangled within the life/death/life cycles of all beings.

I argue that although all human bodies are edible, this is most manifest in the case of feminine/female subjects. In The Sexual Politics of Meat, Carol J. Adams explains how the oppressions of women and of animals are co-implicated. For example, she analyzes the many representations (visual and linguistic) of women as meat, and of animals whom we eat as feminized. This double oppression makes it easier for man to treat both parties as consumable and subordinate. Yet the edible products of the human female body, such as breast milk and placenta are taboo as food. In 2006, performance artist Jess Dobkin's "Lactation Station" pasteurized breast milk bar prompted Health Canada to issue a warning on consuming breast milk (Van Esterik 2012) and despite its source of proteins, eating the placenta or afterbirth is still commonly regarded as disgusting in 'Western,' white, liberal circles (Abrams 2013). At the present moment, women are edible only as flesh, and primarily as a metaphor for sexual consumption. This association of women with edibility is not an inherent property, but a social construction. 
In contrast, the concept of being eaten is erased from the ideal of masculinity: men are portrayed as and disciplined to be the consumers, not the consumed. Men are praised for a voracious appetite and devouring nature (Buerkle 2009). It is an occasion for laughter when a man points out the bloodthirsty nature of vengeful female mosquitoes or praying mantises. Catholics may 'eat' and 'drink' the body of Christ at communion, but his is a metaphorical "body without sin" (Kristeva 120).

In brief, I investigate the role of gender here in order to reveal a point of intersection or co-morbidity: that the non-masculine is one of the places where human edibility is shown, and thus human exceptionalism is undermined. As Simms notes, "the female body is the place where the chiasmic connection between human being and earth becomes apparent" (276).

\section{Being Eaten}

When considering human edibility, we often shrink back in disgust. In Powers of Horror (1982) Julia Kristeva theorized the abject as that which simultaneously horrifies and fascinates us. Abject objects, which include food, the maternal body, and excrement, all traverse or threaten the supposedly impenetrable (masculine) body: "Filth is not a quality in itself, but it applies only to what relates to a boundary and, more particularly, represents the objects jettisoned out of that boundary" (69).

Kristeva's psychoanalytic explanation of abjection can be traced back to infancy: while breastfeeding, the infant first devours the mother's breast. But, in order to become a full subject, the child must reject both the mother and the breast as abject, embracing autonomy and the father. This action is the refusal to eat the mother, to devour her body, and a refusal to see humans as consumable entities. Thus from the first object/abject, human edibility has to be 
removed for the formation of subjectivity. The self becomes propre (clean, proper, and my own) only in the undoing of edibility.

Citing Mary Douglas' research, Kristeva shows that food itself, since it crosses the bodily borders, is abject and filthy. However, "dietary abomination has thus a parallel—unless it be a foundation —in the abomination provoked by the fertilizable or fertile feminine body" (100). The feminine body, and all of its implications of interiority, its leaking parts and expulsions, menstruation and childbirth, is a centrally abject figure. The combination of the two, eating a feminine body, pushes us to the very limits.

In Simms' and Plumwood's accounts of women as food, abjection is multilayered: blurring the borders between humans, between human and non-human animals, and between all animals and the environment. This abjection, I will argue, comes not only from the transgressive and border-crossing nature of human edibility, but also from a confrontation with an ontological and material condition of all life.

In "Eating One's Mother: Female Embodiment in a Toxic World " (2009), Eva-Maria Simms argues for a "placental ethics" based on the relationship of the pregnant or post-partum woman in nourishing the fetus and/or infant. Her work begins by displacing man for his breastfed infant at the top of the food-chain:

When I actually imagine a woman at the top of the food-chain it is not so easy to see the human being as the self-owned and self-contained apex of creation. Rather, the female body is open, a conduit for the next generation, as passage that stretches through time. There is no hierarchical top of the food chain: woman herself becomes food for her young. She is a link and an integrated element in the chain of those who eat and are eaten. (264)

The mother is food, and Simms emphasizes that she is rapidly becoming contaminated food. Our organisms are porous, and so as food we are contaminated by pesticides and biotoxins. This 
contamination has effects on our own bodies first. However, when we are eaten, these toxins continue through the rest of the environment, including other humans (271). Through biomagnification, any toxins that the mother ingests or comes in contact with are transmitted to the fetus in larger concentrations, both through the placenta and through breastfeeding. Our porousness, twinned with our being nutritious, shows that we have "a chiasmic relationship with other humans, but also with space, things, and nonhuman beings" (269).

Simms describes Merleau-Ponty's concept of the chiasm as "the ontological dimension of connectedness between body and world, perceiver and perceived, visible and invisible" (267). It is a heterogeneous unity of difference, where two non-identical sides meet. She argues that this is literally embodied in the placenta: an organ made of the cells of two different beings, which serves to nourish and support both individuals, "not a barrier, but a place of exchange" (271). Indeed, the placenta is an involuntary phenomenon, one with which the pregnant individual cannot but have an intimate involvement.

Simms' placental ethics is both literal and metaphorical: it takes the placenta as exemplary because it is the material place of openness, but urges us to think of all of our interand intra-corporeal relations in the same manner. The placenta exits the human body, showing that it is not concrete, solid, or impenetrable. It crosses these borders abjectly, and is a kind of human flesh that we see die or expire (271-2).

Simms claims that our nested ecosystems - mother in Nature, fetus in the motherreflect the same intertwining as the placenta itself. Breast milk is also a placental being: it too can be contaminated by a variety of factors, and uses the life of one to support another. The chiasm exists across time as well as across individuals: one is eaten now in order for the future to persist. Simms urges us to think not only of what our biotechnology is doing to the 'external' 
environment, but to realize that because of the penetrable nature of humanity we must consider ourselves as food and protect against damage.

In "Tasteless: Towards a Food-Based Approach to Death " (2008a) and "Being Prey" (2008b), Val Plumwood examines being eaten through her own near-death experience of being prey for an alligator. In Kakadu National Park, her canoe was struck by a crocodile, forcing her to jump into the water and fight the crocodile's death rolls and sustained attempts to devour her. After the attack, Plumwood argues that the media tried to impose a master-monster narrative of our supremacy over the environment onto her story, seeing her survival as a triumph of human over animal. At the same time, they took her encounter as evidence that women were not fit for such adventuring, and sexualized the crocodile as sexually assaulting her. In contrast, Plumwood emphasizes that being trapped in the jaws of the crocodile unsettled her subjectivity: it gave her "a glimpse 'from the outside' of the alien, incomprehensible world in which the narrative of self has ended," a world in which human is prey ("Prey"). She argues that isolating humans as exceptional and supreme, at the top of the food chain rather than tangled within it, is not only harmful to our environment but fundamentally wrong and dangerous for ourselves. Human beings "act as if we live in a separate realm of culture in which we are never food, while other animals inhabit a different world of nature in which they are no more than food" ("Prey").

Plumwood argues that our reluctance to acknowledge our own edibility is linked to our reluctance to acknowledge the body-in-death (and so, the body itself). The two paradigms of thought regarding death that dominate today are a "heavenism" that sees the body as "prison of the soul" (which lives on post-corporeal) and a contemporary atheism that equates life and consciousness, regarding death as the end of the person ("Tasteless" 326). In both these cases, 
Plumwood observes, we ignore the "foodiness" or nutritional potential (and actuality) of our bodies for other living beings.

Embracing the life/death/life cycle, Plumwood argues, would be akin to the animism present in Australian Aboriginal narratives and stories. These narratives disrupt the idea of man at the top of the food chain by disrupting the idea of death as finality or emptiness. Life and death can be seen not as linear events or as the beginning and end but as a productive cycle, where being eaten provides a "positive ecological presence, positive traces in the lives of other species" (T 329). Human edibility works (not always, but most often) through human death, just as our eating of non-human animals and plants requires their death(s). Plumwood's contribution thus takes us past the question of inter-human edibility and into inter-animal edibility.

My work here aims to go beyond simply merging Simms and Plumwood's views. Simms' work emphasizes the biological nature of maternity, possibly excluding non-traditional modes of conception and pregnancy. Plumwood's essays, on the other hand, give us a strong reason to consider nature without truly acknowledging human gender oppression. From these narratives, I do not believe that we can explain women being eaten in a simple or single way: there is an 'intertwining' itself: across the human lifespan, we eat and are eaten from womb to tomb, in life and in death.

\section{Onto-Ecology}

I propose that we are food because we are living (eating) and dying: that in order to live and die humans must be edible. The human fetus depends upon the edibility of the placenta, and the newborn upon the edibility of breast milk (or substitutes that are primarily constituted by the mother's milk of other species, usually cows). To continue the propagation of human being, 
humans must be edible. Non-human animals and plants also depend upon our decaying flesh. These material facts, I will argue, provide support for an ontological reversibility based upon that which Merleau-Ponty proposes in The Visible and the Invisible (1968).

Merleau-Ponty argues that being able to see requires that we also be visible to other gazes: otherwise we would have no perspective on the world, or there would be no real sight (133). Likewise, in order to be able to touch things, we are tangible (133). The human self-asbody does not fluctuate between subject (sensing) at one moment and object (sensed) at the next. Rather the sensing and the sensed are the reverse and obverse, or two sides of a single reversibility. This shows not a radical subject-object distinction, but what he calls a chiasmic relationship, or the flesh. As a glove might fold upon itself, and the outside and insides become turned and touching, he insists that perception or sensibility is this movement.

Merleau-Ponty claims that this reversibility is fulfilled or proven when another being (with the power of seeing) gazes upon us (as seer and simultaneously seen) (143). Quite simply, it is fulfilled when I experience myself being watched. In such a moment, I become aware of the simultaneity of experiences which I would ordinarily attribute to 'subject' or 'object', and find that they are neither. Merleau-Ponty even extends this reversibility to figures of nature, citing Paul Klee's comment: "In the forest I have felt many times over that it was not I who looked at the forest. Some days I felt that the trees were looking at me" (Merleau-Ponty, "Eye \& Mind" 167).

Even before we introduce eating, these notions of reversibility, the chiasm, and the flesh are abject. First, they deny an absolute subject, who stands outside of and in external relation to others. Second, they make even the ideal male vulnerable, even if he is so to a lesser degree than 
oppressed individuals. Finally, this reversibility exists in all aspects of nature and so undermines claims to human exceptionalism.

How can eating, or being-eaten take place? If we extend Merleau-Ponty's train of thought, I argue that human beings can only be consumers insofar as we are ourselves consumable/edible. Our visibility, and edibility, open onto the same world, a world intimately shared with others. This means, under it all, that there is an Edibility "in itself, which belong[s] neither to the body qua fact nor to the world qua fact" but to the in-between, the flesh, which is more than the two in combination, something different that is revealed at the touching (139). This fact is fulfilled or proven when we are eaten or we experience our edibility first and foremost. The eater-as-edible is present in both Simms' and Plumwood's papers, revealing ourselves not as self-determining, dominating, pure actors but also as that which can be acted upon. This places us in an onto-ecology that demands reciprocity and awareness, since all beings possess this same reversibility.

\section{Conclusion}

In conclusion, this paper has aimed to explore the philosophical fruitfulness of examining women as food. I have used Simms' and Plumwood's examples to argue that in viewing our human selves as edible creatures, we not only distance ourselves from the role of 'eater' in the masculinist domination framework but reject and break down the very dichotomy of eater/eaten, predator/prey, diner/dinner. Experiences of edibility therefore function as one way to embrace the human-self-body, and relinquish the chains of dualism in favour of a fundamental reversibility. These cases, together with the reversibility theorized by MerleauPonty, point to an asymmetrical yet symbiotic relationship between all organic, decaying, and 
nourishing bodies. As Plumwood says, "We are edible, but we are also much more than edible. Respectful, ecological eating must recognize both of these things" ("Prey"). I have also explained why this is revealed most clearly in cases of women being eaten, due not to essentialism but to the exclusionary discourse that casts both woman and edible in opposition to man.

This work has not only ethical but political implications: viewing women as the locus of edibility can help us challenge both human domination of animals and intra-human domination. Exposing edibility as a feature of all humanity, including the idealized masculinist autonomous subject, can disrupt the devaluation of women, racialized subjects, and people with disabilities and the tight association of these subjects with nature and unintelligence or unintelligibility. Disrupting this association, and revaluing nature, might then give us a way to fight inter-human as well as inter-animal domination.

\section{Works Cited}

Abrams, Lindsay. "Why Some Mothers Choose to Eat Their Placentas." The Atlantic. March 22 2013. Web. Accessed Jul 72013.

Adams, Carol J. The Sexual Politics of Meat: A Feminist-Vegetarian Critical Theory. New York: Continuum, 2000.

Aristotle. Politics. Trans. Benjamin Jowett. The Internet Classics Archives, MIT Department of Classics, 2009. Accessed Jul 12013.

Buerkle, C. Wesley. "Metrosexuality Can Stuff It: Beef Consumption as (Heteromasculine) Fortification.” Text and Performance Quarterly 29, no.1 (2009): 77-93.

Kristeva, Julia. Powers of Horror: An Essay on Abjection. Trans. Leon S. Roudiez. New York: Columbia University Press, 1982. 
Merleau-Ponty, Maurice. "Eye \& Mind." The Primacy of Perception: And Other Essays on Phenomenological Psychology, the Philosophy of Art, History and Politics. Ed. James M. Edie. Trans. William Cobb. Evanston: Northwestern University Press, 1964.

- The Visible and the Invisible. Ed. Claude Lefort. Trans. Alphonso Lingis. Evanston: Northwestern University Press, 1968.

Plumwood, Val. Feminism and the Mastery of Nature. New York: Routledge, 1993.

- "Tasteless: Towards a Food-Based Approach to Death." Environmental Values 17, no. 3 (2008a): 323-330.

—."Being Prey." Remembering Val Plumwood: Val Plumwood.com. (2008b). Accessed March 29, 2013.

Simms, Eva-Maria. "Eating One's Mother: Female Embodiment in a Toxic World." Environmental Ethics 31 (2009): 263-277.

-. "Milk and Flesh: A Phenomenological Reflection on Infancy and Coexistence." Journal of Phenomenological Psychology 32, no. 1 (2001): 22-40.

Van Esterik, Penny. "Vintage Breast Milk: Exploring the Discursive Limits of Feminine Fluids." Taking Food Public: Redefining Foodways in a Changing World. Eds. Psyche Williams-Forson and Carole Counihan. New York: Routledge Press, 2012. 